Klemperer, R. M. M. (1957). J.gen. Microbiol. 16, 299-304

\title{
The Normal Distribution of the Resistance of Coliphage T 3 to Inactivation by Bacterial Receptors and its Application to their Assay
}

\author{
BY RUTH M. M. KLEMPERER \\ Sir William Dunn School of Pathology, University of Oxford
}

SUMMARY: A study of the inactivation of coliphage 'T'3 by its bacterial receptors indicates that the resistance of the phage is variable and conforms to a log normal distribution. Receptor activity can be conveniently assayed using probits to obtain a linear relation between phage survival and receptor concentration. This method is sufficiently sensitive to distinguish between the reactivity of receptors prepared from different bacterial hosts.

Fildes \& Kay (1955), studying adsorption of phage 1 by strains of Salmonella typhi, found that the plot of the log \% phage unadsorbed against time was linear. They obtained the same result for the inhibition of phage 1 by a relatively pure receptor preparation. The time required for the inhibition of $50 \%$ phage was inversely proportional to the receptor concentration, and could be used to estimate receptor concentration. In the present paper it is shown that these relations do not hold for the reaction of coliphage T3 with its receptors. However, it has been found possible to determine receptor concentrations by assuming that the resistance of coliphage T3 particles to inactivation is not uniform but is normally distributed.

\section{METHODS}

Organisms. Escherichia coli B, obtained originally from Dr T. F. Anderson, was kept on Dorset egg medium at room temperature and subcultured every 3 months. Cultures for immediate use were grown on tryptic meat agar from stock cultures.

Salmonella typhi O901R, originally selected from O901S (Fildes \& Kay, 1955), was cultivated in the same way.

Coliphage T3 in high titre was kindly provided by Dr D. Kay (Kay, 1955) and stored at $4^{\circ}$. Tenfold dilutions in buffer (see below) were stored at $4^{\circ}$ to provide inocula for daily use. Titres remained constant for many months.

Estimation of phage. Phage particles were counted by the two-layer method of Hershey, Kalmanson \& Bronfenbrenner (1943), $1 \mathrm{ml}$. phage+bacteria mixture being added to $2 \mathrm{ml}$. peptone agar to make the surface layer.

Preparation of bacterial extracts. For the preparation of extracts of Escherichia coli B, the organism was grown in a Difco Bacto-Casamino acid

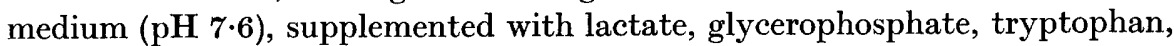
magnesium, manganese, iron and yeast extract, and aerated with air $+5 \%$ $\mathrm{CO}_{2}$ in an apparatus as described by van Heyningen \& Gladstone (1953). The 
organisms were centrifuged off and washed once with water. They were then resuspended in a small volume of water and precipitated with 6 vol. acetone. This was repeated twice more. The precipitate was dried in a desiccator (yield: 4-5 g./l. culture). Dried organisms were extracted 3 to 6 times at $56^{\circ}$ for $1 \mathrm{hr}$. with successive volumes of water, using $10 \mathrm{ml}$. volumes $/ \mathrm{g}$. organisms. The pooled extracts were precipitated with acetic acid at $\mathrm{pH} 4$, the precipitate redissolved in water and the $\mathrm{pH}$ value adjusted to $7 \cdot 6$ with $\mathrm{NaOH}$. The final volume of extract was one-tenth the original volume. The acetic acid precipitation increased the activity per unit volume up to 25 times, in spite of the loss of some activity in the supernatant fluid. O901 R extracts were prepared in the same way.

An O901R extract which had been further purified by sodium chloride precipitation was provided by Dr D. Kay. Unlike the material previously described by him (Kay, 1955), it had a high anti-phage T3 activity, probably because it was the result of a large number of extractions of the acetone-dried organisms.

Buffer. This contained: phosphate $(\mathrm{pH} 7 \cdot 6) \mathrm{m} / 30$ (autoclaved); $\mathrm{MgSO}_{4} \cdot \mathbf{7 H}_{2} \mathrm{O}$ $\mathbf{M} / \mathbf{4 0 0 0}$ (autoclaved); albumin (human) 1/2500 (filtered).

Stock concentrated solutions were sterilized separately and mixed to give the indicated concentrations.

Estimation of receptor activity in bacterial extracts. A sample $(2 \mathrm{ml}$.) of phage ( 5 to $10 \times 10^{3}$ particles $/ \mathrm{ml}$.) in buffer was incubated for $30 \mathrm{~min}$. at $37^{\circ}$. During this time the phage count rose owing to disaggregation of the particles. An equal volume of bacterial extract in buffer was then added, the extract having previously been diluted to give various concentrations of receptors. Samples $(0.5 \mathrm{ml}$.) were withdrawn immediately and after the required time of incubation, and pipetted into $4.5 \mathrm{ml} .1 \%(\mathrm{w} / \mathrm{v})$ peptone water to stop the reaction. One vol. of the diluted material was added to 2 vol. Escherichia coli B culture in peptone water, and the number of phage particles counted (in duplicate or triplicate).

Expression of results. Receptor concentration is expressed throughout as the concentration of bacterial extract used as the source of receptor. In Figs. 2-6, receptor concentrations are expressed as $\log _{2}$ reciprocal of extract concentration, i.e. $-\log _{2}$ extract concentration. All straight lines are calculated as regressions of ordinate upon abscissa. Correlation coefficients were high in all instances $(P=<0.001$ in Figs. 3, 4 and 6, and $<0.01$ in Fig. 5).

\section{RESULTS}

\section{Reaction of coliphage $\mathrm{T} 3$ with bacterial extracts}

When coliphage T3 was incubated with receptor preparations the log percentage phage survival, i.e. unadsorbed phage, fell rapidly during the first minutes of incubation, but later only diminished slowly (Fig. 1). Thus the rate of phage inactivation decreased rapidly with the fall in the concentration of free phage. The plot of percentage phage survival after $30 \mathrm{~min}$. incubation against the log receptor concentration is a sigmoid curve (Fig. 2). This sigmoid curve is 
of the same type as an integrated frequency curve for a normal distribution, since probit percentage phage survival plotted against log receptor concentration gives a straight line (Figs. 3, 4) (Bliss, 1935).

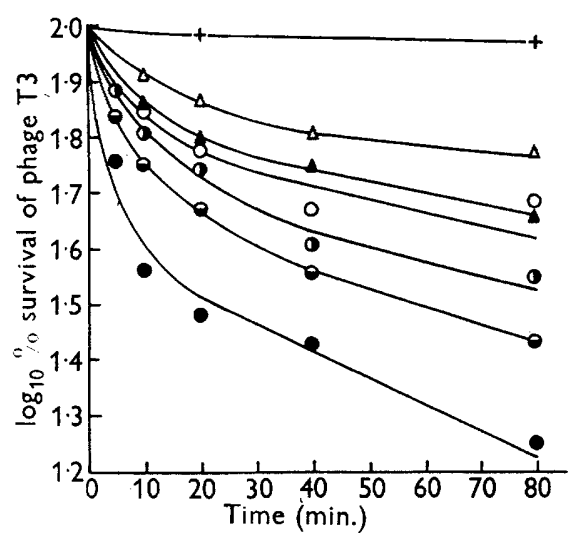

Fig. 1

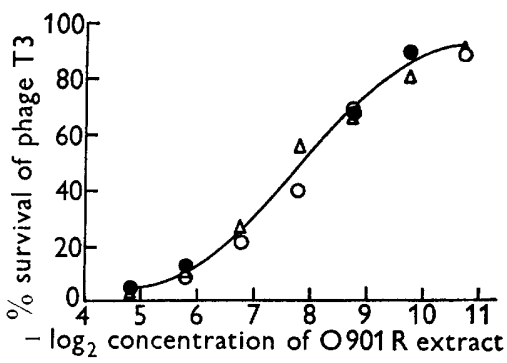

Fig. 2

Fig. 1. Inactivation of phage $\mathrm{T} 3$ by coli $\mathrm{B}$ receptors. Bacterial extract added :,+-+ 0 ; $\triangle-\triangle, 1 / 320 ; \Delta-\Delta, 1 / 160 ; \bigcirc-0,1 / 120 ; 0-0,1 / 80 ; \vartheta-\Theta, 1 / 40 ;$

Fig. 2. Inactivation of phage $T 3$ by $0901 \mathrm{R}$ receptors after $30 \mathrm{~min}$. incubation. The extract used was acid and salt precipitated. The curve is based on results from triplicate experiments represented by $\Theta, O$ and $\Delta$.

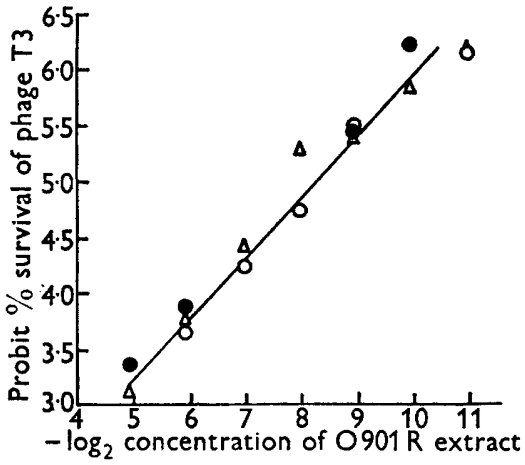

Fig. 3

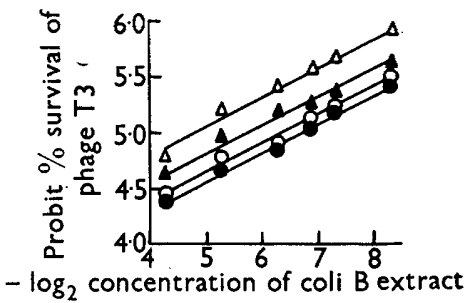

Fig. 4

Fig. 3. Inactivation of phage $\mathrm{T} 3$ by $0901 \mathrm{R}$ receptors after $30 \mathrm{~min}$. incubation. $\odot, O$ and $\triangle$ refer to the same experimental points as in Fig. 2 . Regression coeff : 0.53 ; standard error \pm 0.031 . When probit $\%$ phage survival is $5 \cdot 0,-\log _{2}$ extract concn. (with $95 \%$ confidence limits) is $8 \cdot 18 \pm 0 \cdot 1.1$, i.e. titre of extract is $1 / 290(95 \%$ confidence limits: 1/270-1/315).

Fig. 4. Inactivation of phage $\mathbf{T} 3$ by coli $B$ receptors. These points are calculated from the. curves shown in Fig. 1.

$\begin{array}{cccc}\text { Incubation } & \text { Regression } & \text { Standard } \\ \text { (min.) } & \text { coeff. } & \text { error } \\ \triangle-\triangle & 10 & 0 \cdot 27 & \pm 0 \cdot 016 \\ \Delta-\Delta & 20 & 0 \cdot 24 & \pm 0 \cdot 012 \\ O-0 & 30 & 0 \cdot 25 & \pm 0 \cdot 016 \\ - & 40 & 0.25 & \pm 0.010\end{array}$




\section{Estimation of receptors}

The use of probits provides a convenient method for the assay of receptor activity. The amount of receptor required for $50 \%$ inactivation of phage can be estimated accurately from the plot of probit percentage phage survival against $\log$ receptor concentration. Thus in Fig. 5, the increased concentration of extract required for $50 \%$ inactivation of phage in the presence of antiserum indicates approximately one-third reduction in receptor activity.

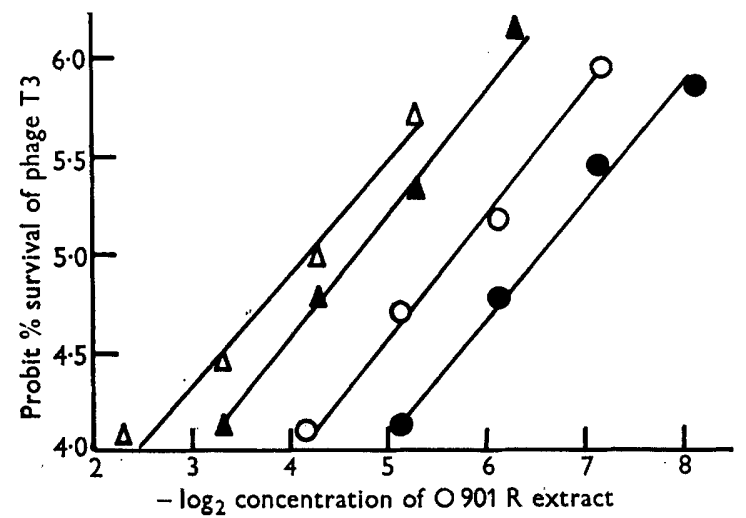

Fig. 5. Inactivation of phage $\mathrm{T} 3$ by $0901 \mathrm{R}$ receptors after $30 \mathrm{~min}$. incubation. Bacterial extracts, at a concentration $c .20$ times that required to inactivate $50 \%$ phage, were incubated with equal volumes of an anti-0901 $\mathrm{R}$ serum diluted $1 / 8$ in buffer, or with equal volumes of buffer only for $30 \mathrm{~min}$. at $37^{\circ}$. They were then diluted and assayed for receptor activity as usual. The serum was prepared by repeated intravenous injections of heat-killed bacteria into a rabbit.

\begin{tabular}{|c|c|c|c|c|c|c|}
\hline 090 & $\begin{array}{l}\text { Anti- } \\
\text { serum }\end{array}$ & $\begin{array}{c}\text { Regression } \\
\text { coeff. }\end{array}$ & & $\begin{array}{c}-\log _{2} \\
\text { extract } \\
\text { concn.* }\end{array}$ & $\begin{array}{c}\text { Therefore } \\
\text { titre of } \\
\text { extract }\end{array}$ & $\begin{array}{c}95 \% \\
\text { confidence } \\
\text { limits }\end{array}$ \\
\hline
\end{tabular}

Acid precipitated

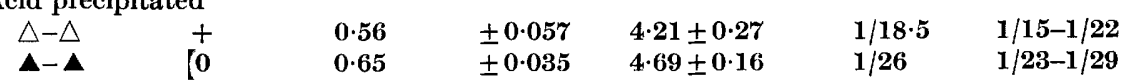

Same preparation as in Fig. 3, but stored 7 months at $4^{\circ}$

$\begin{array}{lllllll}\bigcirc-\bigcirc & + & 0.59 & \pm 0.052 & 5 \cdot 73 \pm 0 \cdot 24 & 1 / 53 & 1 / 45-1 / 63 \\ 0-0 & 0 & 0.59 & \pm 0.050 & 6 \cdot 58 \pm 0.21 & 1 / 96 & 1 / 83-1 / 110\end{array}$

* When probit $\%$ phage survival $=\mathbf{5 \cdot 0}$ (with $95 \%$ confidence limits).

\section{Reactivity of receptors}

The slope of the line relating probit percentage phage survival to log receptor concentration remained constant using different preparations of a receptor. Thus Fig. 5 shows that the slope for $0901 \mathrm{R}$ extract was unaffected when the activity was reduced one-third by treatment with antiserum. Comparison of Fig. 5 with Fig. 3 shows that the slope was also unaltered by further purification of the receptor, or when the receptor was approximately two-thirds inactivated by prolonged storage. Similar experiments showed that the slope for different coli $\mathbf{B}$ receptor preparations was also constant.

However, receptors from the two bacterial species tested were different. This is shown by the observation that the slope of probit percentage phage 
survival against log concentration of $0901 \mathrm{R}$ receptor (Fig. 3) is always twice as great as that for coli $\mathrm{B}$ receptors (Fig. 4). (The regression coefficients differ significantly: $P=0 \cdot 02-0 \cdot 01$; Student's $t$ test.)

\section{DISCUSSION}

The sigmoid relation between the survival of coliphage T3 and the log receptor concentration suggests that the coliphage T3 particles are heterogeneous in their resistance to inactivation. As the plot of the probit percentage phage survival against log receptor concentration is linear, the resistance of the phage particles to inactivation may be assumed to be normally distributed in relation to the log receptor concentration. In this respect, the resistance of coliphage $\mathbf{T} 3$ to inactivation resembles that of bacteria, animals and plants to toxic agents (Gaddum, 1933; Withell, 1942). It would be expected from Withell's work that the resistance of phage particles to inactivation would also be normally distributed with respect to log time for any concentration of receptor. The results given here are in accordance with this when plotted appropriately, but do not extend over a long enough period of time to be conclusive.

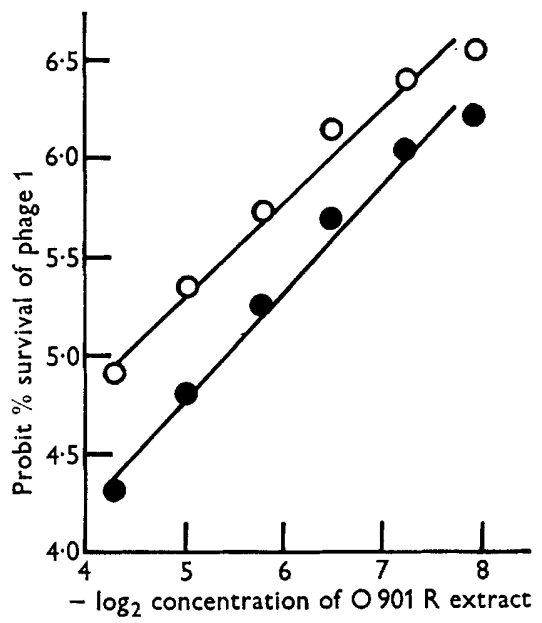

Fig. 6. Inactivation of phage 1 by $0901 \mathrm{R}$ receptors. These points are calculated from data supplied by Dr D. Kay. The extract used was acid and salt precipitated.

$\begin{array}{cccc}\text { Incubation } & \text { Regression } \\ \text { (min.) } & \text { eoeff. } & \begin{array}{c}\text { Standard } \\ \text { error }\end{array} \\ \bigcirc-0 & 10 & 0.49 & \pm 0.034 \\ -0 & 20 & 0.56 & \pm 0.034\end{array}$

The plot of log percentage survival against time was not linear for coliphage T3, unlike the linear relationship found by Fildes \& Kay (1955) for phage 1. A linear relationship is of the same type as that of a first-order reaction in which the reactants are uniform. However, the behaviour of phage 1 may also be interpreted in terms of a normal distribution since the relationship between 
probit percentage survival and log receptor concentration is linear (Fig. 6: data kindly supplied by Dr Kay). This is in agreement with the findings of Withell (1942) that any observed form of time-survival curve can be represented approximately as a normal distribution when time or concentration of the toxic agent is plotted logarithmically. It suggests that phage 1 may also be heterogeneous like coliphage T3. The heterogeneity of phages in other respects is well known. For example, Burnet, Keogh \& Lush (1937) found in several cases that phages varied in their resistance to inactivation by antibody, some showing typical log normal distributions.

Burnet et al. (1937) showed that the receptor for Shigella flexneri phage was heterogeneous in its ability to combine with phage, and in general crude extracts were more avid than purer fractions. No evidence was obtained in the experiments described here of any difference in the reactivity of different receptor preparations. However, it was of interest that the slopes of inactivation of coliphage 'T3 by receptors prepared from two bacterial hosts were different. It is possible that the steeper slope obtained with $0901 \mathrm{R}$ receptor is due to greater avidity.

This work was carried out in collaboration with the British Empire Cancer Campaign Virus Research Unit, and my thanks are due to Sir Paul Fildes, F.R.S., the Director, for his interest in it. I also wish to thank Dr G. P. Gladstone and Dr D. Kay for much useful advice. The work was done during the tenure of a Phillip Walker Studentship.

\section{REFERENCES}

Burss, C. I. (1935). The calculation of the dosage-mortality curve. Ann. appl. Biol. 22, 134.

Burnet, F. M., Keogh, E. N. \& Lush, D. (1937). The immunological reactions of the filterable viruses. Aust. J. exp. Biol. med. Sci. 15, 227.

FIldES, P. \& KAY, D. (1955). The rate of adsorption of bacteriophage by rough and smooth strains of Salmonella typhi. Brit. J. exp. Path. 36, 534.

Gaddum, J. H. (1933). Reports on biological standards. III. Methods of biological assay depending on a quantal response. Spec. Rep. Ser. med. Res. Coun., Lond. no. 183.

Hershey, A. D., Kalmanson, G. \& Bronfenbrenner, J. (1943). Quantitative methods in the study of the phage-antiphage reaction. J. Immunol. 46, 267.

Heyningen, W. E. van \& Gladstone, G. P. (1953). The neurotoxin of Shigella shigae. 1. Production, purification and properties of the toxin. Brit. J. exp. Path. 34, 202.

KAY, D. (1955). The reactions of certain bacteriophages with their receptors isolated from Salmonella typhi O901 R. Brit. J. exp. Path. 36, 290.

Withell, E. R. (1942). The significance of the variation in shape of time-survivor curves. J. Hyg., Camb. 42, 124. 